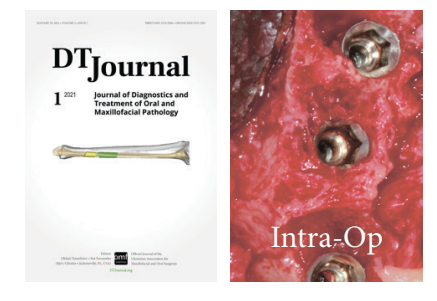

\title{
Private Practice, Implantology, and Continuing Professional Development
}

\author{
Ivan V. Nagorniak
}

Strength and growth come only through continuous effort and struggle.

-Napoleon Hill

American self-help author

\section{Continuing professional development (CPD)} (synonym: continuing education [CE] $)^{1}$ in Ukrainian stomatology reached a new level in 2019 by the Order (\# 446, dated February 22) entitled "Some issues of CPD of doctors" was officially published. ${ }^{2}$ According to new Order of Ministry of Healthcare of Ukraine, ${ }^{3}$ every physician-stomatologist must score:

1. 50 CPD points obtained in 2020 or 2021 for certification in 2021.

2. 100 CPD points obtained in 2020 and 2021 for certification in 2022.

3. 150 CPD points obtained in 2020,2021 , and 2022 for certification in 2023.

The CPD points can be scored for a wide variety of activities, like: 1) participation in scientific and practical conference, congress or symposium, 2) distance (digital) learning using electronic learning resources, 3) thematic training (professional schools,

Oral Surgeon (Physician-Stomatologist-Surgeon), PhD

Private Practice, 6-G Andruschenka Street, Office 6

Kyiv 01135, Ukraine

E-mail: ivan.nagorniak@gmail.com

Please cite this article as: Nagorniak IV. Private practice, implantology, and continuing professional development. J Diagn Treat Oral Maxillofac Pathol 2021;5(1):10-2.

The abbreviation 'Intra-Op' at the upper right icon means that article contains intraoperative photographs. seminars, workshops, etc.), 4) study or internship at a university or health care institution - in Ukraine or abroad, 5) publication of an article in a peer-review journal, etc. ${ }^{3}$

Attestation is needed 1) to continue (or to obtain a right) practicing in a certain specialty, 2) to confirm the assigned qualification category or a new higher one assignment. ${ }^{4}$

The Procedure for attestation of doctors notes that it is aimed to improve the activities of health care institutions of all forms of ownership. ${ }^{4}$ Physicianstomatologist-surgeon (ie, oral surgeon) who moves own private surgical practice forward is more than interested in obtaining the Second, First and Highest qualification category. Special motivation of the surgeon to obtain the categories is usually driven by the wish to perform dental implantation (Fig 1) and bone grafting procedures. For example, according to the instructions (approved by the order of the Ministry of Health of Ukraine) the physicianstomatologist-surgeon of the Second qualification category among other surgical procedures must be able to perform dental implantation and related manipulations within the alveolar process without additional bone grafting. ${ }^{5}$ Also, the instructions

Paper received 21 January 2021

Accepted 23 January 2021

Available online 29 January 2021

https://dx.doi.org/10.23999/j.dtomp.2021.1.3

(c) 2021 OMF Publishing, LLC. This is an open access article under the CC BY license (http://creativecommons.org/licenses/by-nc/4.0/). 
for the physician-stomatologist-surgeon of the First qualification category note that among other surgical procedures the surgeon must be able to perform dental implantation and related manipulations using bone grafting materials and intraoral blocks. ${ }^{6}$ physician- stomatologist-surgeon of the Higher qualification category must be able to perform all types of dental implantation and related manipulations within and outside the alveolar process using extraoral blocks and fixation of exoprostheses. ${ }^{7}$

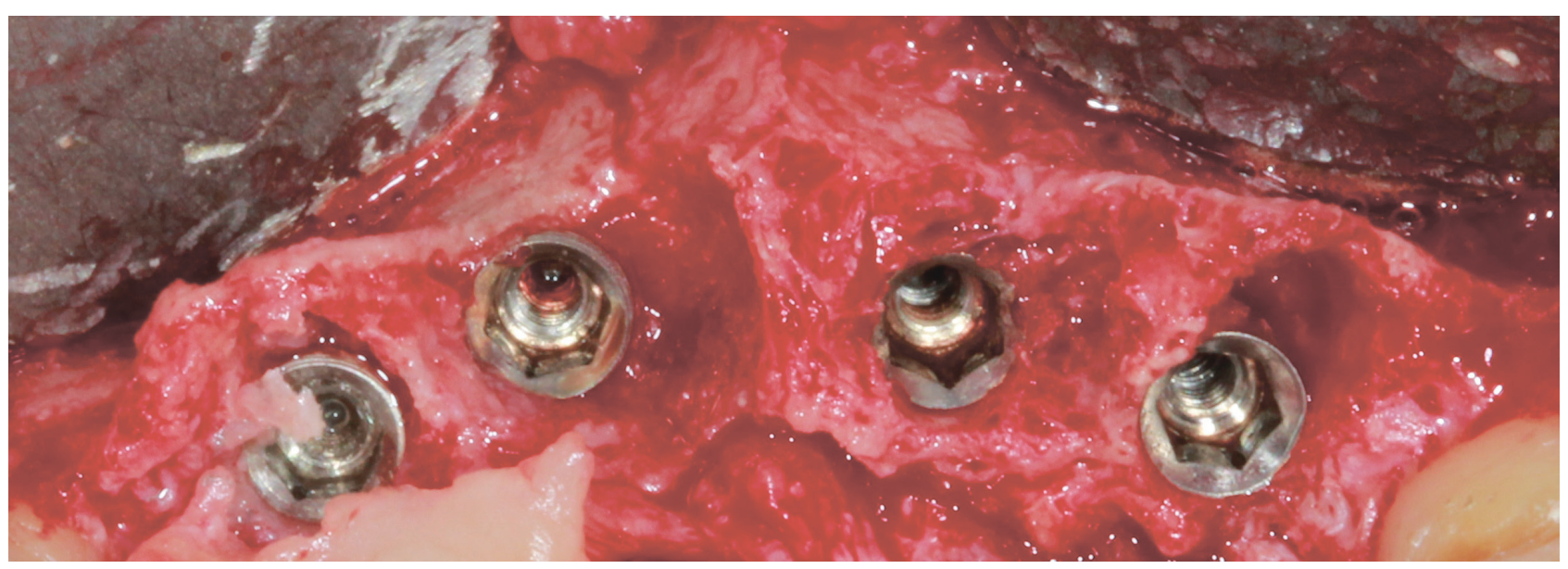

FIGURE 1. Dental implantation at the anterior maxilla.

Publication of the scientific paper (case report, ${ }^{8}$ case series, images ' article, ${ }^{9}$ viewpoint, ${ }^{10}$ etc.) is a great option for every stomatologist in Ukraine as it will bring 20 or $30 \mathrm{CPD}$ points depending it's a publication in Ukrainian or English language peerreviewed journal (Table 1). ${ }^{3}$

TABLE 1. Number of Scored CPD Points for the Published Article.

\begin{tabular}{|c|c|}
\hline $\begin{array}{c}\text { Ukrainian Language Peer- } \\
\text { reviewed Journal }\end{array}$ & $\begin{array}{c}\text { English Language Peer- } \\
\text { reviewed Journal }\end{array}$ \\
\hline 20 CPD points & 30 CPD points \\
\hline
\end{tabular}

Analyzing CPD in other countries and CPD`s relation with journals it's worth to notice that, for example, Australian Dental Journal (Impact Factor: 1.401; 2019 Journal Citation Reports (Clarivate Analytics): 66/91 (Dentistry, Oral Surgery \& Medicine) $)^{11}$ which has an oral and maxillofacial surgery section, also publishes CPD Quiz with scoring the points for the readers. ${ }^{12}$

Moreover, some journals, like Oral Diseases journal (Impact Factor: 2.613; 2019 Journal Citation Reports (Clarivate Analytics): 19/91 (Dentistry, Oral Surgery \& Medicine), ${ }^{13}$ even score points for the review of the articles.
In summary, it's became more and more popular worldwide to score CPD points for the physicians who read, review the articles or who publish the peer-reviewed papers, like in Ukraine from 2019. In my opinion, this way of rewarding readers, reviewers and authors has an extremely positive effect on the growth of doctors as professionals, their domestic/ international cooperation and the development of specialties and journals.

\section{REFERENCES}

1. Sambrook P, Goss A. Continuing education for oral and maxillofacial surgeons--new expectations. Ann $R$ Australas Coll Dent Surg 1996;13:193-7.

2. Order of the Ministry of Health of Ukraine dated 22.02.2019 \# 446 "Some issues of continuous professional development of doctors" [document on the internet]; February 22, 2019 [cited 2021 Jan 21]. Available from: https://moz.gov.ua/article/ministrymandates/nakaz-moz-ukraini-vid-22022019-446-dejaki-pitannja-bezperervnogo-profesijnogorozvitku-likariv

3. How are the points of continuing professional development for doctors scored: examples [document on the internet]; February 22, 2019 [cited 2021 Jan 21]. Available from: https://moz.gov.ua/ article/for-medical-staff/jak-narahovujutsja-balibezperervnogo-profesijnogo-rozvitku-likarjam- 
prikladi

4. Procedure for attestation of doctors [document on the internet]; February 29, 2019 [cited 2021 Jan 21]. Available from: https://moz.gov.ua/uploads/2/11598dn_20190222_446_dod_por.pdf

5. Job instruction: physician-stomatologist-surgeon of the second qualification category [document on the internet]; September 15, 2019 [cited 2021 Jan 21]. Available from: https://www.borovik.com/index_ instruction.php?Gins=wcmn\&lang_ $\mathrm{i}=1$

6. Job instruction: physician-stomatologist-surgeon of the first qualification category [document on the internet]; September 15, 2019 [cited 2021 Jan 21]. Available from: https://www.borovik.com/index instruction.php?Gins=wcml\&lang_i $\mathrm{i}=1$

7. Job instruction: physician-stomatologist-surgeon of the higher qualification category [document on the internet]; September 15, 2019 [cited 2021 Jan 21]. Available from: https://www.borovik.com/index_ instruction.php? Gins=wcmq\&lang_i $=1$

8. Nagorniak KY, Nagorniak IV. Buccal plate preservation at anterior maxilla using immediate implant placement with a 2.0 -mm gap technique based on spontaneous bone healing: case report. $J$ Diagn Treat Oral Maxillofac Pathol 2018;2(4):151-4. https://doi.org/10.23999/j.dtomp.2018.4.2

9. Nagorniak IV. Clinical appearance of lateral incisive canal. J Diagn Treat Oral Maxillofac Pathol 2019;3(8):200. https://doi.org/10.23999/j. dtomp.2019.8.4

10. Nagorniak IV. Sinus lift: analysis of Schneiderian membrane perforations. J Diagn Treat Oral Maxillofac Pathol 2020;4(10):191-3. https://doi.org/10.23999/j. dtomp.2020.10.2

11. Australian Dental Journal [document on the internet]; January 21, 2020 [cited 2021 Jan 21]. Available from: https://onlinelibrary.wiley.com/journal/18347819

12. CPD Quiz: multiple choice questions [document on the internet]; December 22, 2020 [cited 2021 Jan 21]. Available from: https://onlinelibrary.wiley.com/ doi/10.1111/adj.12805

13. Oral Diseases [document on the internet]; January 21, 2020 [cited 2021 Jan 21]. Available from: https:// onlinelibrary.wiley.com/journal/16010825 